\title{
Monoclonal antibody A7-superparamagnetic iron oxide as contrast agent of MR imaging of rectal carcinoma
}

\author{
A Toma ${ }^{1,3}$, E Otsuji, I,3, Y Kuriu', K Okamoto', D Ichikawa', A Hagiwara', H Ito², T Nishimura² ${ }^{2}$ and \\ H Yamagishi'
}

'Department of Surgery, Kyoto Prefectural University of Medicine, 465 Kawaramachi Hirokoji Kamigyo-ku, Kyoto 602-8566, Japan; ${ }^{2}$ Department of Radiology, Kyoto Prefectural University of Medicine, 465 Kawaramachi Hirokoji Kamigyo-ku, Kyoto 602-8566, Japan

\begin{abstract}
Superparamagnetic iron oxide (SPIO)-based colloid has been used clinically as a tissue-specific magnetic resonance contrast agent. We coupled monoclonal antibody A7 (Mab A7), which reacts specifically with human colorectal carcinoma, to Ferumoxides (SPIO) and examined the accumulation of this conjugate in xenografted tumours in nude mice. We examined in vitro immunoreactivity of Mab A7 coupled to Ferumoxides and its in vivo distribution in nude mice with human colorectal carcinoma. Magnetic resonance imaging of tumour-bearing nude mice was performed $72 \mathrm{~h}$ after injection of A7-Ferumoxides. A7-Ferumoxides retained binding activities that were nearly identical to intact Mab A7. More of the radiolabelled A7-Ferumoxides accumulated in the tumour than normal mouse lgG-Ferumoxides from $12 \mathrm{~h}$ onwards after injection $(P<0.05)$. Both A7-Ferumoxides and normal mouse lgGFerumoxides disappeared from blood linearly over time. The accumulation levels in normal tissue decreased linearly over time but were lower than levels in tumours from $6 \mathrm{~h}$. In magnetic resonance T2-weighted imaging of the tumour-bearing nude mice, signal intensity was reduced at the margin of the tumour by injection of A7-Ferumoxides. Mab A7 coupled to Ferumoxides is potentially suitable as a magnetic resonance contrast agent for detecting local recurrence of rectal carcinoma.
\end{abstract}

British Journal of Cancer (2005) 93, I31-136. doi: I0.1038/sj.bjc.6602668 www.bjcancer.com

Published online 21 June 2005

(c) 2005 Cancer Research UK

Keywords: recurrence of rectal carcinoma; magnetic resonance imaging; contrast agent; monoclonal antibody; superparamagnetic iron oxide

As chemotherapy, radiotherapy, and thermotherapy adjuncts to surgical treatment are performed for rectal carcinoma, the survival rate has improved in recent years (Hildebrandt et al, 2000; Adell et al, 2001; Frykholm et al, 2001). Total mesorectal excision for rectal cancer has reduced the rate of local recurrence and raised overall survival. Yet, local recurrence, which is the most common pattern in rectal carcinoma, occurs in approximately $8-15 \%$ of patients even after curative surgery (Goldberg and Nicholls, 1995; Wibe et al, 2003). Moreover, a diagnostic problem is represented by the difficult differentiation of local recurrence from postoperative fibrosis by either computed tomography (CT) or magnetic resonance (MR) imaging (Balzer et al, 2003). The development of contrast agents which accumulate in rectal carcinoma might eventually improve its prognosis.

Although MR imaging currently is considered the most accurate method for diagnosing local recurrence, unenhanced and gadolinium-enhanced MR imaging are not sensitive enough for differentiation between local recurrence and other tissues. Magnetic resonance imaging techniques have been proposed,

*Correspondence: Dr E Otsuji, Department of Surgery, Kyoto Prefectural University of Medicine, 465 Kajii-cho Kamigyo-ku, Kyoto 602-8566, Japan; E-mail: otsuji@koto.kpu-m.ac.jp

${ }^{3}$ These two authors contributed equally to this work

Revised 7 March 2005; accepted I8 May 2005; published online 21 June 2005 including the use of ferromagnetic particles $\left(\mathrm{Fe}_{3} \mathrm{O}_{4}\right)$ as MR contrast agents (Mendonca-Diasand and Lauterbur, 1986; Renshaw et al, 1986a, b). Superparamagnetic iron oxide (SPIO)-based colloid has been investigated as an MR contrast agent (Weissleder et al, 1987a,b). Ferumoxides, one SPIO-based colloid, has been used clinically as a tissue-specific MR contrast agent in order to distinguish liver tumours (Clement et al, 1991). No MR contrast agent has been shown to detect the local recurrence of rectal carcinoma.

We have previously reported that monoclonal antibody A7 (Mab A7), produced from human colonic carcinoma, reacts immunohistochemically with colorectal carcinomas with high sensitivity (Otsuji et al, 1992; Takahashi et al, 1993). In this study, we coupled Mab A7 to Ferumoxides in order to examine whether the complex would be useful as an MR contrast agent for local recurrence of rectal carcinoma.

\section{MATERIALS AND METHODS}

\section{Cell line}

WiDr, the human colonic carcinoma cell line, was used in this study. WiDr cells were incubated in RPM1 1640 media supplemented with $10 \%$ foetal bovine serum (FBS) in an atmosphere of $5 \% \mathrm{CO}_{2}$ and air at $37^{\circ} \mathrm{C}$. 


\section{Tumour xenograft}

Cultured WiDr cells were harvested by ethylenediamine tetraacetic acid (EDTA) treatment, washed, and resuspended in PBS. Approximately $10^{7}$ viable cells were injected subcutaneously into the backs of athymic 8-week-old nude mice (BALB/C-nu/nu, male, mean body weight: approximately $25 \mathrm{~g}$ ) (Shimizu, Shizuoka, Japan). A tumour mass was detected in all mice injected with WiDr cells 14 days after inoculation.

\section{Monoclonal antibody A7}

Monoclonal antibody A7 was produced from spleen cells of a mouse immunised against human colonic adenocarcinoma, Colon 6 (Kotanagi et al, 1986). Monoclonal antibody A7 belongs to the $\mathrm{IgG}_{1}$ subclass and recognises a $42000 \mathrm{Da}$ glycoprotein on the cell surface. It has been reported to react with more than $70 \%$ of human colorectal carcinoma cell lines (Takahashi et al, 1993), but it does not react immunohistochemically with normal tissues. Normal mouse IgG was purchased from Sigma-Aldrich (St Louis, MO, USA).

\section{Preparation of radiolabelled Mab}

Radiolabelling of Mab A7 with ${ }^{125}$ I (Amersham Japan, Tokyo) was performed by the chloramine-T method (Hunter and Greenwood, 1962). The iodinated Mab A7 was separated from excess reactants by passage through a Sephadex G-25 column. Monoclonal antibody A7 was labelled with ${ }^{125} \mathrm{I}$ to specific activities of $5.0 \mu \mathrm{Ci} \mu \mathrm{g}^{-1}$. As a control, normal mouse IgG also was labelled with ${ }^{125} \mathrm{I}$ by a similar method.

\section{Preparation of SPIO}

Ferumoxides, a SPIO - based colloid, was obtained from Advanced Magnetics Co. (Cambridge, MA, USA). Ferumoxides is a colloid of SPIO ( $\mathrm{FeO}$ and $\mathrm{Fe}_{2} \mathrm{O}_{3}$ ) supported with dextran $\mathrm{T}-10$, and the mean diameter of particles is approximately $100 \mathrm{~nm}$. It contained $11.2 \mathrm{mg} \mathrm{Fe} \mathrm{ml}^{-1}$.

\section{Mab A7 coupled to Ferumoxides}

Monoclonal antibody A7 was coupled with the dextran of Ferumoxides using a modification of the sodium periodate method (Molday and Mackenzie, 1982). In all, $1 \mathrm{ml}$ of Ferumoxides was added to $10 \mathrm{~mm}$ sodium periodate. The dextran of Ferumoxides was partially oxidised. The reaction was carried out for $60 \mathrm{~min}$ at room temperature with stirring, the oxidised Ferumoxides was separated from residual periodate by passage through a Sephadex G-25 column. Then $3 \mathrm{mg}$ of Mab A7 was added to the solution of oxidised Ferumoxides. The aldehyde functions of oxidised dextran react with the amino sites of Mab A7 to form Schiff bases. The conjugation reaction was carried out for $24 \mathrm{~h}$ at room temperature with stirring, $0.5 \mathrm{ml}$ of $1 \%$ sodium borohydride solution was then added in order to reduce the product to secondary amine linkages. After $15 \mathrm{~min}$, the reaction was terminated by dialysing against $0.1 \mathrm{M}$ sodium phosphate buffer. Ferumoxides coupled to antibody was separated from unconjugated antibody by centrifugation for $15 \mathrm{~min}$ at $15000 \mathrm{rpm}$. The supernatant was discarded, and the pellet containing the A7-Ferumoxides complex was resuspended. Similarly, Ferumoxides was coupled to normal mouse IgG as a control. Approximately $20 \%$ of the initially added antibody was coupled with Ferumoxides.

\section{Stability of A7-Ferumoxides in human serum \\ ${ }^{125}$ I-labelled A7-Ferumoxides $(0.5 \mathrm{mg})$ was added to volunteer human serum $(0.5 \mathrm{ml})$, and the serum was allowed to clot in}

humidified $\mathrm{CO}_{2}\left(37^{\circ} \mathrm{C}, 5 \% \mathrm{CO}_{2}\right.$ atmosphere). At 24,72 , and $120 \mathrm{~h}$ after incubation, ${ }^{125} \mathrm{I}$-labelled A7-Ferumoxides was separated from unconjugated antibody by centrifugation for $15 \mathrm{~min}$ at $15000 \mathrm{rpm}$. Radioactivities of $100 \mu 1$ of each supernatant were counted with a gamma scintillation counter (COBRA 5002/5003, Packard, CO, USA) and were compared with the count of the supernatant of the sample prior to incubation.

\section{In vitro binding activities of $\mathrm{A} 7$-Ferumoxides to $\mathrm{WiDr}$ cells}

The binding activities of A7-Ferumoxides were examined by a competitive inhibition radioimmunoassay in WiDr cells. Aliquots of WiDr cells $\left(10^{6}\right)$ were incubated with a fixed quantity of ${ }^{125} \mathrm{I}$ labelled A7 $\left(10^{5} \mathrm{cpm}\right)$ in the presence of serially four-fold diluted A7-Ferumoxides or intact $\mathrm{A} 7$ at $37^{\circ} \mathrm{C}$ for $60 \mathrm{~min}$. The concentration of A7-Ferumoxides and intact A7 ranged from $10.0 \times 4^{-6}$ to $10.0 \mu \mathrm{g} \mathrm{ml}^{-1}$. As a control, normal mouse IgG-Ferumoxides was used instead of A7-Ferumoxides or intact A7. After incubation, the cells were washed three times with PBS. Radioactivity of the cell pellets was counted with a gamma scintillation counter (COBRA $5002 / 5003$, Packard), and the percent inhibition was calculated compared to the results of only ${ }^{125}$ I-labelled A7.

\section{Biodistribution of ${ }^{125}$ I-labelled A7-Ferumoxides in nude mice bearing human colorectal carcinoma xenografts}

The biodistribution of ${ }^{125}$ I-labelled A7-Ferumoxides was examined in nude mice bearing WiDr tumours. At 14 days after inoculation, 48 tumour-bearing nude mice were divided into two groups: 24 mice in one group were injected intravenously with $1.0 \mu \mathrm{Ci}$ of

${ }^{125}$ I-labelled A7-Ferumoxides via the tail vein, 24 mice in another group were injected with $1.0 \mu \mathrm{Ci}$ of ${ }^{125} \mathrm{I}$-labelled normal mouse IgG-Ferumoxides. Three mice from each group were killed and dissected at 2, 6, 12, 24, 48, 72, 96 and $120 \mathrm{~h}$ after injection. After dissection, the tumours, blood, and normal organs (lung, heart, liver, spleen, pancreas, stomach, colon, and kidney) were weighed. The mean weight of the tumours was $178 \mathrm{mg}$. The radioactivity in each tissue was counted with a gamma scintillation counter. The results are expressed as the percentage of the injected dose $\mathrm{g}^{-1}$ $\left(\% \mathrm{ID} \mathrm{g}^{-1}\right)$. Furthermore, to compare the kinetics of the two probes in the tumour, blood, and normal tissues, the tissue/blood ratios of the radioactivity per unit weight were calculated from these data. Student's $t$-test was used to determine statistically significant differences which were set at $P<0.05$. Care of the animals and the experimental procedures were carried out in accordance with the guideline of the United Kingdom Co-ordinating Committee on Cancer Research (UKCCCR, 1998).

\section{MR imaging of nude mice bearing human colorectal carcinoma xenografts}

A WiDr tumour-bearing nude mouse was studied under pentobarbital anaesthesia $72 \mathrm{~h}$ after injection of A7-Ferumoxides. All MR images were obtained with a $1.5 \mathrm{~T}$ clinical scanner with a small field of view (FOV) coil (Eclipse 1.5 T, Marconi Medical systems, UK). These images were obtained with a gradient echo sequence, so-called ' $\mathrm{T} 2^{*}$ '. We used $\mathrm{T} 2^{*}$ sequences to visualise the uptake of SPIO because the $\mathrm{T} 2^{*}$ sequence was the most sensitive at visualising the magnetic susceptibility. A tumour-bearing nude mouse injected with IgG-ferumoxides was imaged at the same time.

\section{RESULTS}

\section{Stability of A7-Ferumoxides in human serum}

Radioactivities of each supernatant at 24,72, and $120 \mathrm{~h}$ after incubation of ${ }^{125}$ I-labelled A7-Ferumoxides with human serum 
were almost identical to that of background and to supernatant before incubation.

\section{In vitro binding activities of A7-Ferumoxides to $\mathrm{WiDr}$ cells}

The binding activities of A7-Ferumoxides were compared with those of intact Mab A7 by a competitive inhibition radioimmunoassay in WiDr cells. Mab A7-Ferumoxides retained binding activities which were nearly identical to intact Mab A7 (Figure 1). Normal mouse IgG-Ferumoxides did not react with WiDr cells.

\section{Biodistribution of ${ }^{125}$ I-labelled A7-Ferumoxides in nude mice bearing human colorectal carcinoma xenografts}

Significantly larger amounts of the ${ }^{125}$ I-labelled A7-Ferumoxides accumulated in the tumour than ${ }^{125}$ I-labelled normal mouse IgG-Ferumoxides from 12 to $120 \mathrm{~h}$ after injection $(P<0.05)$. (Figure 2). The tumour accumulation level of ${ }^{125}$ I-labelled A7-Ferumoxides increased gradually, and radioactivity reached $9.87 \pm 2.96 \% \mathrm{ID} \mathrm{g}^{-1} 24 \mathrm{~h}$ after injection and then decreased slowly. By contrast, the tumour accumulation level of ${ }^{125}$ I-labelled normal mouse IgG-Ferumoxides decreased after radioactivity reached only $3.76 \pm 0.48 \% \quad \mathrm{ID} \mathrm{g}^{-1}$ at $12 \mathrm{~h}$ after injection. ${ }^{125}$ I-labelled A7-Ferumoxides and ${ }^{125}$ I-labelled normal mouse IgG-Ferumoxides disappeared from blood linearly over time with similar clearance curves (Figure 3). As for all resected normal tissues, the accumulation levels of ${ }^{125}$ I-labelled A7-Ferumoxides decreased linearly over time and were lower than those for tumours from $6 \mathrm{~h}$ onwards after injection (Figure $4 \mathrm{~A}-\mathrm{H}$ ). Accumulations of ${ }^{125}$ I-labelled A7-Ferumoxides and ${ }^{125}$ I-labelled normal mouse IgG-Ferumoxides were similar in normal tissues. To examine the specific localisation of ${ }^{125}$ I-labelled A7-Ferumoxides and ${ }^{125}$ I-labelled normal mouse IgG-Ferumoxides in tumours, the ratio of radioactivity in tumour and normal tissues to blood was determined. The tumour/blood ratio of the ${ }^{125}$ I-labelled A7Ferumoxides increased in a time-dependent manner to $2.23 \pm 0.48$ at $72 \mathrm{~h}$ after injection. By contrast, the tumour/blood ratio of ${ }^{125} \mathrm{I}-$ labelled normal mouse IgG-Ferumoxides was lower than that of ${ }^{125}$ I-labelled A7-Ferumoxides (Figure 5).

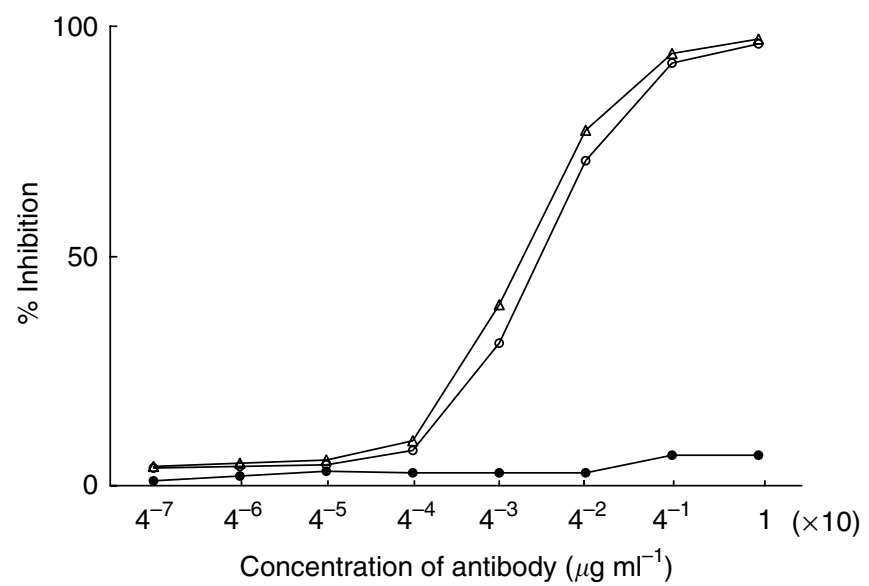

Figure I The binding activities of A7-Ferumoxides were compared with those of intact $\mathrm{A} 7$ by competitive radioimmunoassay in WiDr cells. A7Femmoxides retained binding activities nearly identical to intact A7. Normal mouse IgG-Ferumoxides had no antigen-binding activity in WiDr cells. $\mathrm{O}$, A7-Ferumoxides; $\triangle$, intact A7; $\boldsymbol{0}$, normal mouse IgG-Ferumoxides.

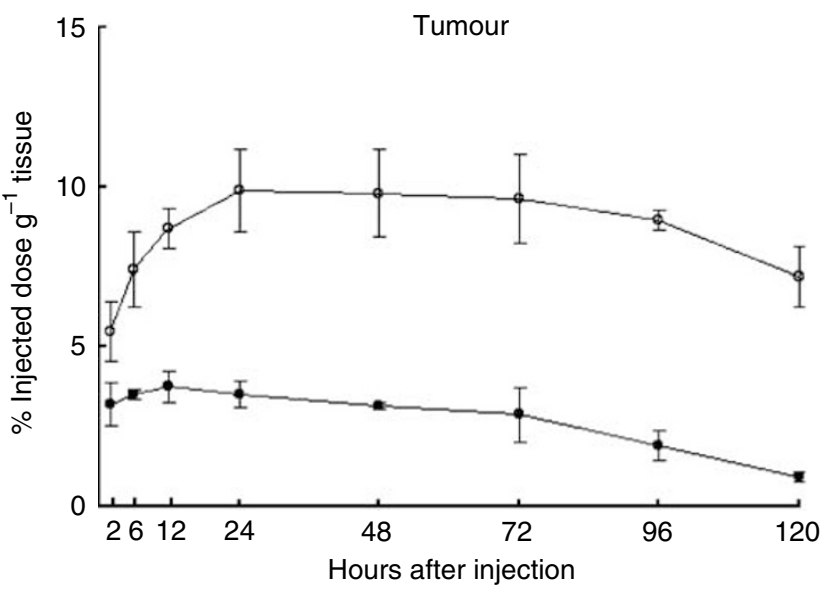

Figure 2 The accumulation of ${ }^{125}$-labelled A7-Ferumoxides and ${ }^{125}$ labelled normal mouse lgG-Ferumoxides in WiDr tumours of mice after intravenous injection. A significantly larger amount of ${ }^{125}$ I-labelled A7Ferumoxides accumulated in the tumour than ${ }^{125}$-labelled normal mouse IgG-Ferumoxides from 12 to $120 \mathrm{~h}$ after injection $(P<0.05)$. The tumour accumulation of ${ }^{125}$-labelled A7-Ferumoxides increased up to $48 \mathrm{~h}$ and then decreased slowly. O, A7-Ferumoxides; - normal mouse IgGFerumoxides; points, means; bars, s.d.

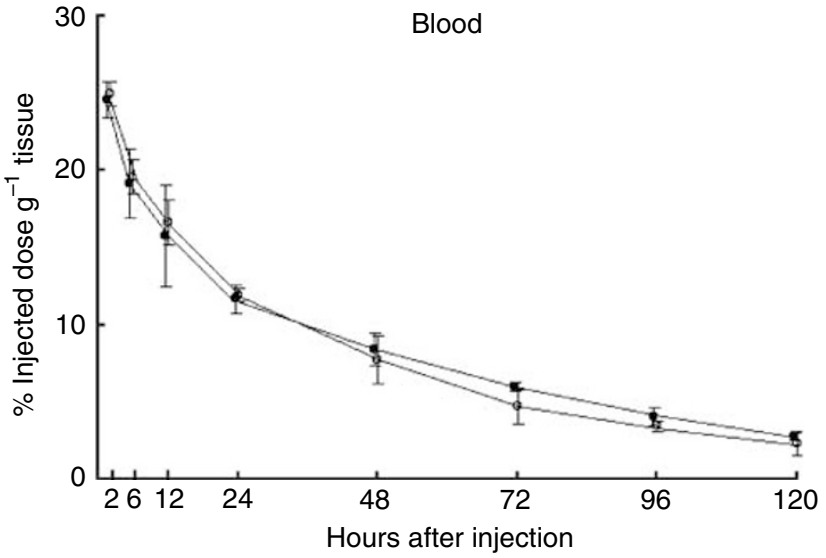

Figure 3 Blood concentrations of ${ }^{125}$-labelled A7-Ferumoxides and ${ }^{125}$ labelled normal mouse lgG-Ferumoxides in mice that received an intravenous injection. ${ }^{125}$-labelled A7-Ferumoxides and ${ }^{125}$ I-labelled normal mouse IgG-Ferumoxides disappeared from blood linearly over time, with similar clearance curves. $\bigcirc$, A7-Ferumoxides; - normal mouse IgG-Ferumoxides; points, means; bars, s.d.

\section{MR imaging of human nude mice bearing human colorectal carcinoma xenografts}

As shown in Figure 6, the signal intensity of MR T2-weighted imaging was reduced at the margin of tumours in a A7Ferumoxides-injected mouse. By contrast, there was no change in intensity in tumours of a normal mouse IgG-Ferumoxidesinjected mouse.

\section{DISCUSSION}

Computed tomography and MR imaging are used currently for diagnosing postoperative local recurrence of rectal carcinoma. Although MR imaging is more successful than CT in the differentiation of local recurrence from postoperative fibrosis 

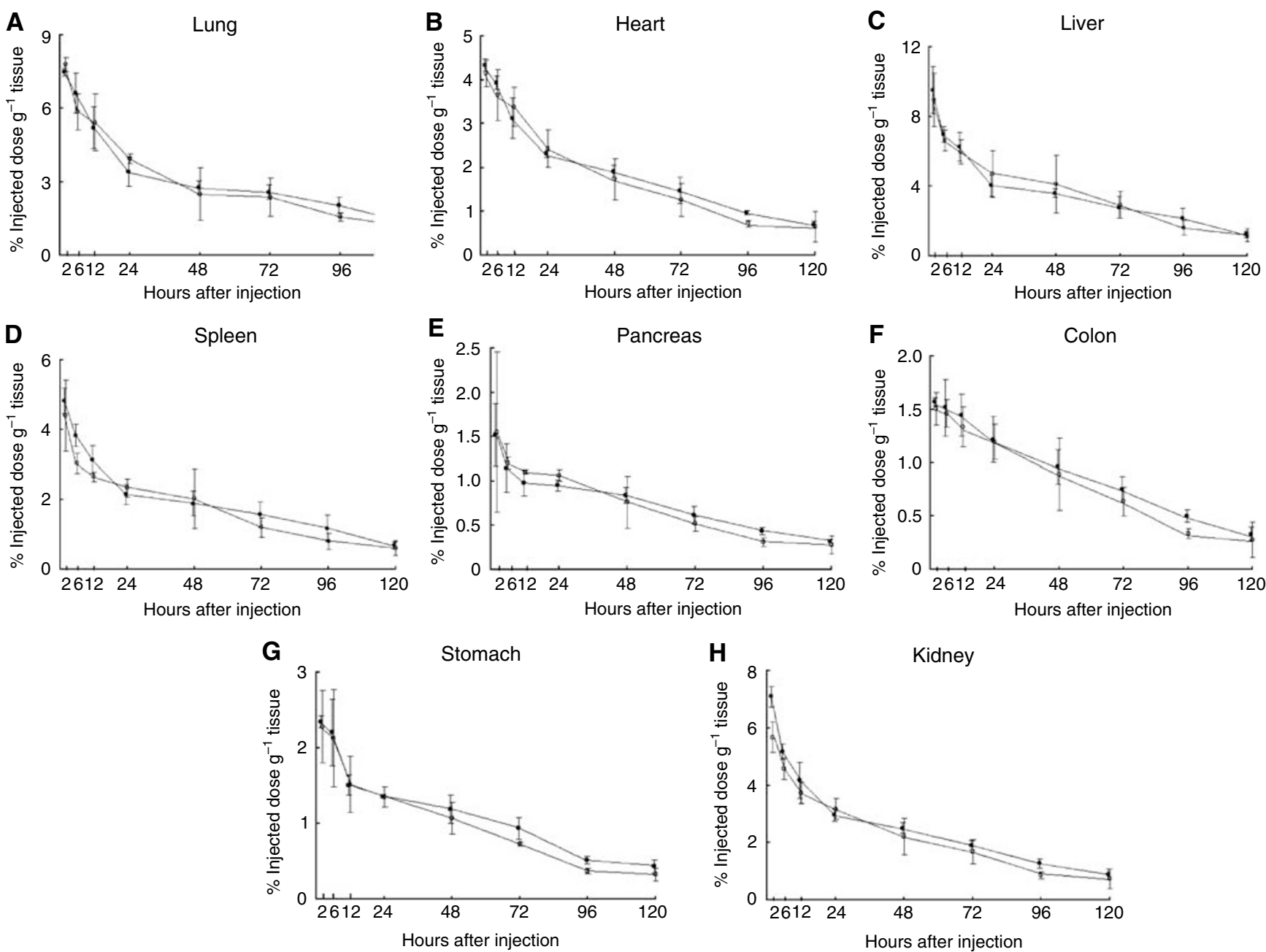

Figure $4 \mathbf{A}$ to $\mathbf{H}$. The accumulation of ${ }^{125}$-labelled A7-Ferumoxides and ${ }^{125}$-labelled normal mouse lgG-Ferumoxides in normal tissues of mice after intravenous injection. The accumulation of ${ }^{125}$-labelled A7-Ferumoxides and ${ }^{125}$ I-labelled normal mouse IgG-Ferumoxides was similar in normal tissues. 0 , A7-Ferumoxides; - normal mouse IgG-Ferumoxides; points, means; bars, s.d.

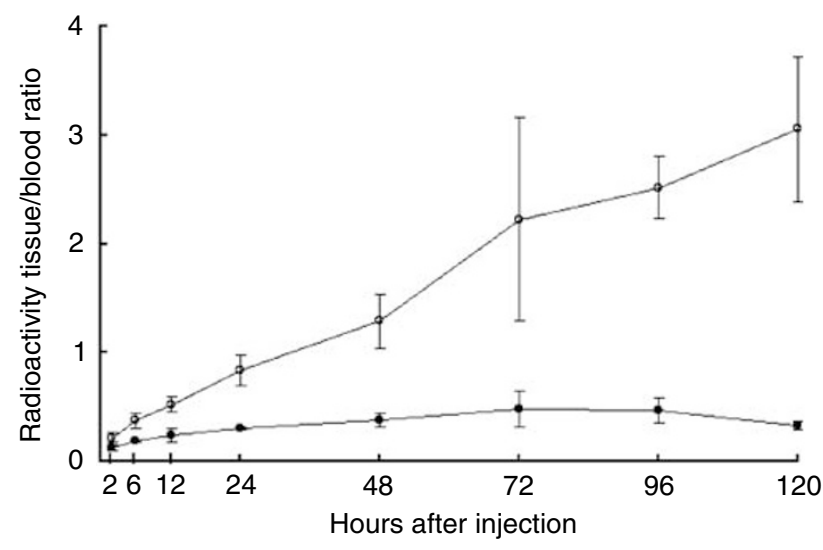

Figure 5 Tumour/blood radioactivity ratio of ${ }^{125}$-labelled A7-Ferumoxides and ${ }^{125}$-labelled normal mouse IgG-Ferumoxides in mice after intravenous injection. The tumour/blood radioactivity ratio of the ${ }^{125}$ |labelled A7-Ferumoxides increased rapidly with time. O, A7-Ferumoxides; - normal mouse lgG-Ferumoxides; points, means; bars, s.d.

based on differences in signal intensity on T2-weighted images (Krestin et al, 1988), the diagnosis of local recurrence at early stages is often difficult. In many cases, tumours already have

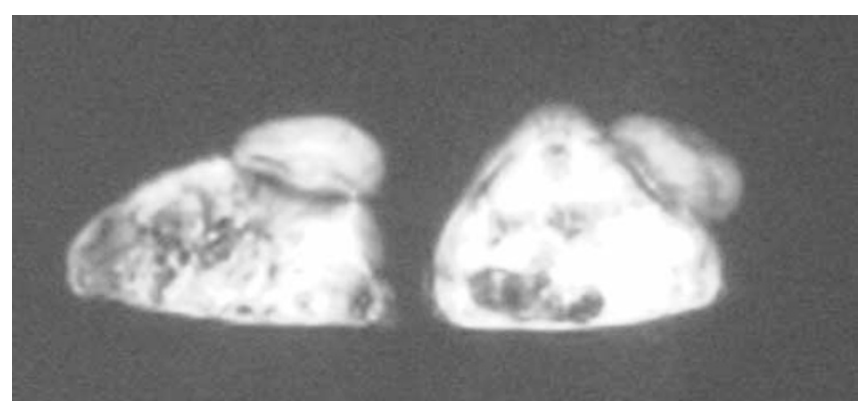

IgG-Ferumoxides

A7-Ferumoxides

Figure 6 The signal intensity of MR T2-weighted imaging was reduced at the margin of tumours in an A7-Ferumoxides-injected mouse. By contrast, there was no change in intensity in tumours of a control lgG-Ferumoxidesinjected mouse.

enlarged and invaded adjacent organs by the time of detection. Improvement of the prognosis might be expected from earlier diagnosis.

Recently, the clinical value of advanced imaging techniques for differentiation between local recurrence and other tissues has been evaluated. Positron emission tomography (PET) can complement 
MR imaging in the differential diagnosis between recurrent tumour and postoperative scar (Ito et al, 1992; Takeuchi et al, 1999). The values of CEA scintigraphy and dynamic MR imaging have also been evaluated (Muller-Schimpfle et al, 1993; Blomqvist et al, 1996; Jarv et al, 2000; Torricelli et al, 2003).

In the field of MR contrast agents, the usefulness of ferromagnetic colloidal particles coated with methacrylate copolymers coupled to antibodies has been reported (Renshaw et al, 1986a). Superparamagnetic iron oxide-based colloids as tissuespecific contrast agents have been developed. Superparamagnetic iron oxide produces dephased adjacent protons with loss of signal intensity in specific organs at low doses. Superparamagnetic iron oxide is magnetised within an external magnetic field and loses magnetisation without an external magnetic field. It disturbs a local magnetic field and shortens the transverse relaxation time. Ferumoxides and Ferucarbotran, which are SPIO-based colloids, are used clinically as liver-targeted MR contrast agents. They are trapped in phagocytic cells of the reticuloendothelial system and reduce the signal intensity of normal liver tissue in T2-weighted pulse sequences. As the signal intensity of the liver tumour without the reticuloendothelial system does not change, the contrast between liver tumours and normal liver tissues is improved. However, a contrast agent that is useful for local recurrence of rectal carcinoma has not been developed. We considered that development of an MR contrast agent that accumulates specifically in rectal carcinoma could make detection of local recurrence easier and lead to improvement of curability. We examined whether Mab A7 is applicable to an MR contrast agent for local recurrence of rectal carcinoma.

We have previously coupled Mab A7 with ferromagnetic particles (Bio-Mag4100) and reported its usefulness in rectal carcinoma (Kotani, 1995). However, it disappeared from the blood relatively slowly, and the tumour to blood ratio was not high enough to distinguish recurrent tumour reliably by MR imaging of patients (unpublished data). If SPIO is carried into tumour by monoclonal antibody, it is useful as an MR contrast agent for detection. We successfully coupled Mab A7 with Ferumoxides, and the immunoreactivity of the complex was retained. A7-Ferumoxides was stable in human serum for at least 5 days. Larger amounts of the complex accumulated in tumour than did normal mouse IgG-Ferumoxides. Furthermore, a larger amount of ${ }^{125} \mathrm{I}$ labelled A7-Ferumoxides accumulated in the tumour than in either blood or normal tissues. A7-Ferumoxides accumulated specifically in the tumour by antigen-antibody-specific binding. A7-Ferumoxides may therefore accumulate in recurrent tumours if administered to patients with local recurrence of rectal carcinoma. In MR imaging of nude mice bearing human colorectal carcinoma, the signal intensity was reduced at the margin of the tumour by injection of A7-Ferumoxides. The reason for the heterogeneity of localisation of A7-Ferumoxides in tumour may be explained by differences in blood supply within the tumour. In a previous study using ${ }^{131}$ I-labelled Mab A7, more antibody was localised at the margin than at the centre of a WiDr tumour by radioautography (unpublished data).

From these results, we conclude that Mab A7 coupled to Ferumoxides is potentially useful as an MR contrast agent for local recurrence of human rectal carcinoma.

\section{ACKNOWLEDGEMENTS}

This work was supported by the Foundation for Promotion of Cancer Research in Japan and by a Grant-in-Aid from the Pancreatic Research Foundation of Japan.

\section{REFERENCES}

Adell G, Zhang H, Jansson A, Sun XF, Stal O, Nordenskjold B (2001) Decreased tumor cell proliferation as an indicator of the effect of preoperative radiotherapy of rectal cancer. Int J Radiat Oncol Biol Phys 50: $659-663$

Balzer JO, Luboldt W, Vogl TJ (2003) Importance of CT and MRI in the follow-up of patients with rectal cancer. Radiologie 43: 122-127

Blomqvist L, Holm T, Goranson H, Jacobsson H, Ohlsen H, Larsson SA (1996) MR imaging, CT and CEA scintigraphy in the diagnosis of local recurrence of rectal carcinoma. Acta Radiol 37: 779-784

Clement O, Frija G, Chambon C, Schouman-Clayes E, Mosnier JF, Poupon MF, Balkau B (1991) Liver tumors in cirrhosis: experimental study with SPIO-enhanced MR imaging. Radiology 180: $31-36$

Frykholm GJ, Pahlman L, Glimelius B (2001) Combined chemo- and radiotherapy $v s$ radiotherapy $v s$ radiotherapy alone in the treatment of primary, nonresectable adenocarcinoma of the rectum. Int $J$ Radiat Oncol Biol Phys 50: 427-434

Goldberg PA, Nicholls RJ (1995) Prediction of local recurrence and survival of carcinoma of the rectum by surgical and histopathological assessment of local clearance. Br J Surg 82: 1054-1056

Hildebrandt B, Wust P, Rau B, Schlag P, Riess H (2000) Regional hyperthermia for rectal cancer. Lancet 356: 771-772

Hunter WM, Greenwood FC (1962) Preparation of iodine, ${ }^{131}$ I-labelled human growth hormone of high specific activity. Nature 194: $495-496$

Ito K, Kato T, Tadokoro M, Ishiguchi T, Oshima M, Ishigaki T, Sakuma S (1992) Recurrent rectal cancer and scar: differentiation with PET and MR imaging. Radiology 182: 549-552

Jarv V, Blomqvist L, Holm T, Ringertz H, Jacobsson H (2000) Added value of CEA scintigraphy in the detection of recurrence of rectal carcinoma. Acta Radiol 41: 629-633

Kotanagi H, Takahashi T, Masuko Y, Hashimoto Y, Koyama K (1986) A monoclonal antibody against human colon cancers. Tohoku J Exp Med 148: $353-360$
Kotani T (1995) Experimental study of immunoguided surgery production of tumor specific monoclonal antibody A7-magnetic iron oxide particle conjugate. J Kyoto Prefectural Univ Med 104: $1217-1224$

Krestin GP, Steinbrich W, Friedmann G (1988) Recurrent rectal cancer: diagnosis with MR imaging versus CT. Radiology 168: 307-311

Mendonca-Diasand MH, Lauterbur PC (1986) Biological trace elements research. Magn Reson Med 3: 328

Molday RS, Mackenzie D (1982) Immunospecific ferromagnetic irondextran reagents for the labeling and magnetic separation of cells. J Immunol Methods 52: 353-367

Muller-Schimpfle M, Brix G, Layer G, Schlag P, Engenhart R, Frohmuller S, Hess T, Zuna I, Semmler W, van Kaick G (1993) Recurrent rectal cancer: diagnosis with dynamic MR imaging. Radiology 189: $881-889$

Otsuji E, Yamaguchi Y, Yamaguchi N, Koyama K, Imanishi J, Yamaoka N, Takahashi T (1992) Expression of the cell surface antigen detected by the monoclonal antibody A7 in pancreatic carcinoma cell lines. Jpn J Surg 22: $351-356$

Renshaw PF, Owen CS, Evans AE, Leigh Jr JS (1986a) Immunospecific NMR contrast agents. Magn Reson Imaging 4: 351 - 357

Renshaw PF, Owen CS, McLaughlin AC, Frey TG, Leigh Jr JS (1986b) Ferromagnetic contrast agents: a new approach. Magn Reson Med 3: $217-225$

Takahashi T, Yamaguchi T, Kitamura K, Noguchi A, Honda M, Otsuji E. (1993) Follow-up study of patients treated with monoclonal antibodydrug conjugate: report of 77 cases with colorectal cancer. Jpn J Cancer Res 84: $976-981$

Takeuchi O, Saito N, Koda K, Sarashina H, Nakajima N (1999) Clinical assessment of positron emission tomography for the diagnosis of local recurrence in colorectal cancer. Br J Surg 86: 932-937

Torricelli P, Pecchi A, Luppi G, Romagnoli R (2003) Gadolinium-enhanced MR1 with dynamic evaluation in diagnosing the local recurrence of rectal cancer. Abdom Imaging 28: 19-27 
United Kingdom Co-ordinating Committee on Cancer Research (UKCCCR) (1998) Guidelines for the welfare of animals in experimental neoplasia (Second Edition). Br J Cancer 77: 1-10

Weissleder R, Hahn PF, Stark DD, Rummeny E, Saini S, Wittenberg J, Ferucci JT (1987a) MR imaging of splenic metastasis: ferrite-enhanced detection in rats. Am J Radiol 149: $723-726$
Weissleder R, Stark DD, Compton CC, Wittenberg J, Ferrucci JT (1987b) Ferrite-enhanced MR imaging of hepatic lymphoma: an experimental study in rats. Am J Radiol 149: $1161-1165$

Wibe A, Eriksen MT, Syse A, Myrvold HE, Soreide O, On behalf of The Norwegian Rectal Cancer Group (2003) Total mesorectal excision for rectal cancer - what can be achieved by a national audit? Colorectal Dis 5: $471-477$ 